\section{Radon variability due to floor level in two typical residential buildings in Serbia}

\author{
Vladimir Udovicic $(\mathbb{D}$, \\ Nikola Veselinovic, \\ Dimitrije Maletic, \\ Radomir Banjanac, \\ Aleksandar Dragic, \\ Dejan Jokovic, \\ Mihailo Savic, \\ David Knezevic, \\ Maja Eremic Savkovic
}

\begin{abstract}
It is well known that one of the factors that influence the indoor radon variability is the floor level of the buildings. Considering the fact that the main source of indoor radon is radon in soil gas, it is expected that the radon concentration decreases at higher floors. Thus at higher floors the dominant source of radon is originating from building materials, and in some cases there may be deviations from the generally established regularity. In such sense, we chose one freestanding single-family house with loft and other 16-floor high-rise residential building for this study. The indoor radon measurements were performed by two methods: passive

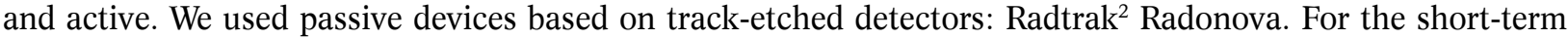
indoor radon measurements, we used two active devices: SN1029 and SN1030 (manufactured by Sun Nuclear Corporation). The first device was fixed in the living room at the ground level and the second was moved through the floors of the residential building. Every measuring cycle at the specified floor lasted seven days with the sampling time of $2 \mathrm{~h}$. The results show two different indoor radon behaviours regarding radon variability due to floor level. In the single-family house with loft we registered intense difference between radon concentration in the ground level and loft, while in the high-rise residential building the radon level was almost the same at all floors, and hence we may conclude that radon originated mainly from building materials.
\end{abstract}

Keywords: Radon variability • Time series

V. Udovicic ${ }^{\bowtie}$, N. Veselinovic, D. Maletic, R. Banjanac, A. Dragic, D. Jokovic, M. Savic, D. Knezevic

Institute of Physics Belgrade

University of Belgrade

Pregrevica 118 St., 11080 Belgrade, Serbia

E-mail: udovicic@ipb.ac.rs

M. Eremic Savkovic

Serbian Radiation and Nuclear Safety and Security

Directorate

Masarikova 5 St., 11000 Belgrade, Serbia

Received: 30 November 2019

Accepted: 17 January 2020

\section{Introduction}

Radon sources in the buildings are primarily from soil, building materials and water. Considering the nature of the occurrence and all the sources, the concentration of radon is higher in the ground-floor rooms compared with that in the higher floors of the dwellings in apartments. In the literature one can find a lot of papers dealing with the influence of various factors, including the floor levels, on the radon concentration and variability. In one group of the articles, investigation of the indoor radon concentration distribution due to floor levels of the buildings is the part of the data analysis which was drawn from the national or regional radon surveys [1-6] and others are dedicated to these specific studies [7-11]. In the case of the big buildings with a several number of floors a deviation from the general regularity can be observed, since the dominant source of indoor radon at higher floors is building materials. On the other hand, the radon variability due to floor level, especially in big cities with a much higher number of highrise buildings and population density compared with rural environments, may have an impact on the assessments of the effective dose from radon exposure at the national level. Usually, the indoor radon map represents the arithmetic mean value of indoor radon concentration on the ground floor, and thus it is not 
representative of the radon exposure to all citizens since most people do not live on the ground floor. So, it is necessary to convert indoor radon map to a dose map. One of the examples is presented as a plan to develop models that allow correction from groundfloor dwellings to the real situation, accounting data from the national buildings database [12]. In Serbia, national typology of residential buildings is based on the results from the monography "National typology of residential buildings of Serbia" by a group of authors from the Faculty of Architecture [13]. There are six types of the residential buildings in Serbia: two for family housing - freestanding single-family house and single-family house in a row and four types for multifamily housing - freestanding residential building and residential building (lamella) (apartment block with repeated multiple lamellar cores and separate entrances), residential building in a row, and high-rise residential building. Distribution of buildings by type at the national level shows that $97 \%$ of all residential buildings are family housing. Also, for all defined types of buildings, number of floors ranges from one to eight above the ground level. Freestanding family houses are mostly ground floor $(37 \%)$ or ground floor with loft in use $(26 \%)$, while there is a very low representation of houses that have more than two floors (5\%), with average floor level of family buildings of 1.4 [13]. In such sense, we chose one freestanding single-family house with loft with well-known radon characteristics [14] and one 16-floor high-rise residential building for this study.

\section{Materials and methods}

Two housing units were selected, one from the family housing group and one high-rise residential building from the collective housing group. The family house has a characteristic construction style in which the house has been built for several years with constant upgrading, which can potentially be a source of radon entry into such houses. The house has a basement and is made of standard materials (brick block, concrete, plaster). Finally, insulation was made using $5-\mathrm{cm}$ thick styrofoam. Long-term measurements of radon concentrations have been carried out in this house by various methods, and several scientific papers have been published so far [14-16].
From the group of residential buildings for collective housing, we chose high-rise building in New Belgrade. It was built in the 1960s as block type. The soliter has a basement, while on the ground floor there are outlets and business premises. The apartments are located in the first floor upward. The soliter has 16 floors. One of the important parameters in the selection of building in municipality New Belgrade is the fact that this municipality is the most populated in Serbia.

The long-term radon measurements were performed with passive device Radtrak ${ }^{2}$ Radonova based on CR-39 track detector. The detectors were exposed for three months from March to June. In the high-rise building, passive radon detectors were deployed at some of the floors in one or several apartments. Time series of measured radon concentrations in the studied residential buildings were obtained using two active devices: SN1029 with the following characteristics declared by the manufacturer - the measurement ranging from $1 \mathrm{~Bq} \cdot \mathrm{m}^{-3}$ to $99.99 \mathrm{kBq} \cdot \mathrm{m}^{-3}$, accuracy equal to $\pm 25 \%$, sensitivity of 0.16 counts/h/Bq.m ${ }^{-3}$ and SN1030 with the following characteristics - the measurement ranging from $1 \mathrm{~Bq} \cdot \mathrm{m}^{-3}$ to $99.99 \mathrm{kBq} \cdot \mathrm{m}^{-3}$, accuracy equal to $\pm 20 \%$, sensitivity of 0.4 counts $/ \mathrm{h} / \mathrm{Bq} \cdot \mathrm{m}^{-3}$. SN1029 device were calibrated at the accredited metrological Lab (SUJCHBO Kamenna, Czech Republic) in 2015 and model SN1030 were calibrated by the manufacturer in 2017 . The both instruments participated in 2018 NRPI Intercomparisons of radon gas continuous monitors and also, SN1029 device participated in 2015 NRPI Intercomparisons of radon gas measurement devices at SURO v.v.i. Institute, Prague, Czech Republic within the IAEA Technical Cooperation Projects RER 9153 and RER 9127, with excellent results. These are measuring devices of simple construction and practical application. It is a counter with the addition of a sensor for measuring meteorological parameters. The operator can adjust the time sequences from $0.5 \mathrm{~h}$ to $24 \mathrm{~h}$. One measurement cycle can take $1000 \mathrm{~h}$ or a total of 720 time sequences (the number of successive measurements, i.e. points in a time series). The devices were set to operate in a 2-h time sequence. One was fixed in the downstairs living room and the other was fixed in repositioning floors in apartment buildings. Each measurement cycle on a given floor lasted seven days.

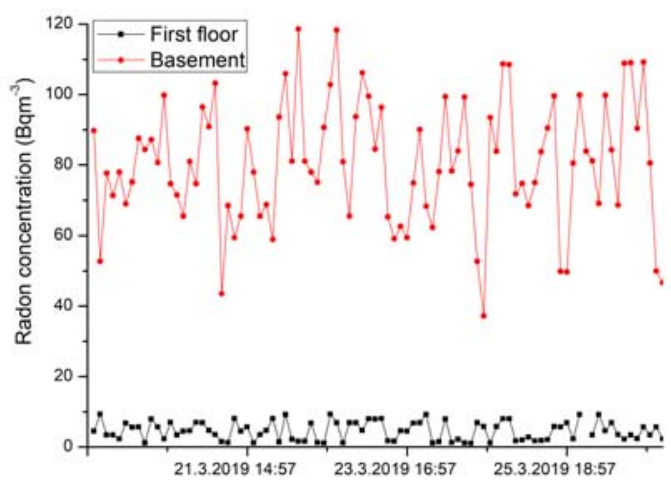

a

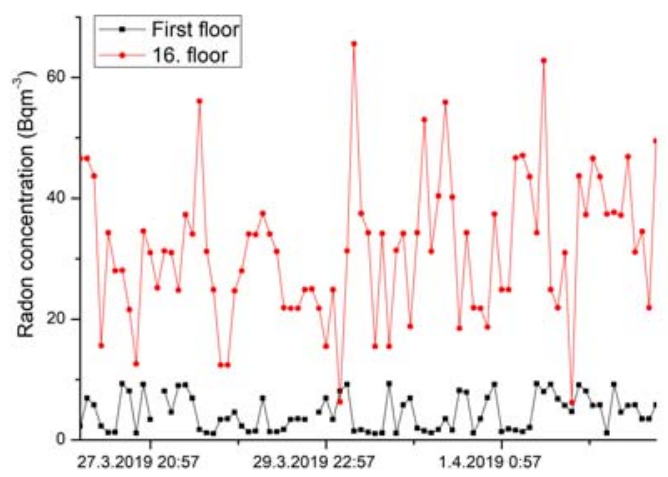

Fig. 1. The time series of the radon concentrations at the first floor vs. basement (a) and 16th floor (b) in the big residential building. 

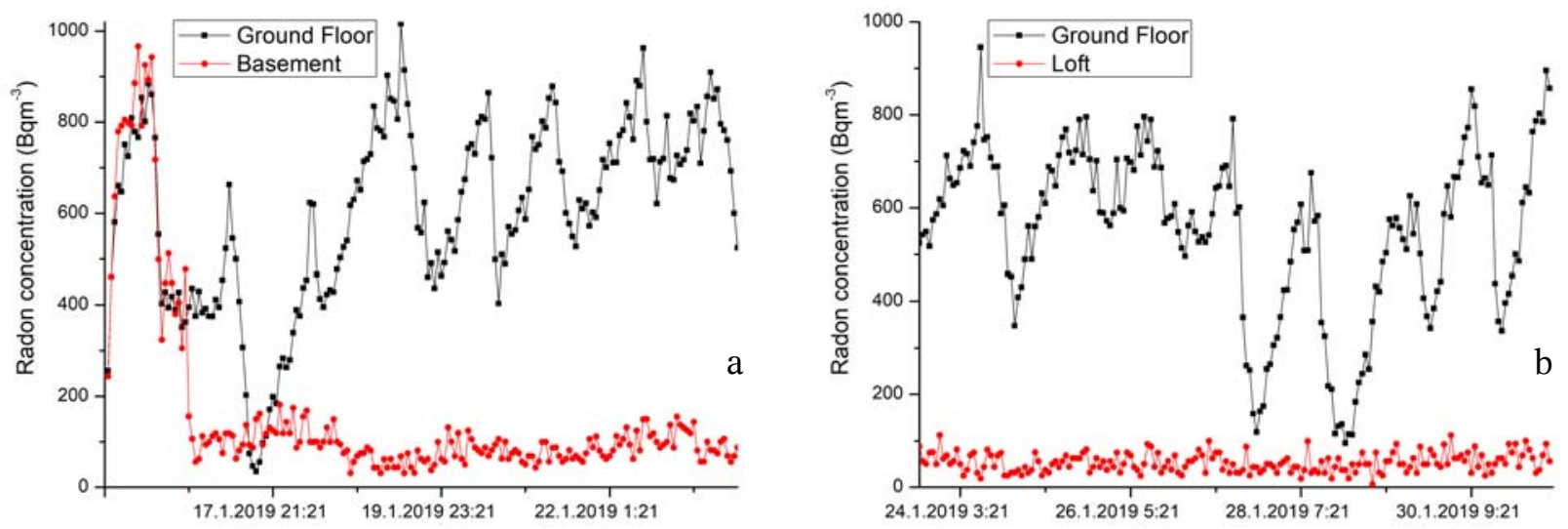

Fig. 2. The time series of the radon concentrations at the first floor vs. basement (a) and loft (b) in the single-family house.

Table 1. Results of indoor radon measurements in the high-rise residential building using passive (Radtrak ${ }^{2}$ Radonova) and active radon devices

\begin{tabular}{|c|c|c|c|}
\hline $\begin{array}{l}\text { Floor } \\
\text { level }\end{array}$ & $\begin{array}{c}\text { Radon } \\
\text { concentration/ } \\
\text { Passive device } \\
\left(\mathrm{Radtrak}^{2}\right) \\
{\left[\mathrm{Bq} \cdot \mathrm{m}^{-3}\right]}\end{array}$ & $\begin{array}{c}\text { Average } \\
\text { radon } \\
\text { concentration } \\
\text { per floor level } \\
\left(\text { Radtrak }{ }^{2}\right) \\
{\left[\mathrm{Bq} \cdot \mathrm{m}^{-3}\right]}\end{array}$ & $\begin{array}{c}\text { Arithmetic } \\
\text { mean } \\
\text { (standard } \\
\text { deviation) } \\
\text { radon } \\
\text { concentration } \\
\text { over } \\
\text { measuring } \\
\text { cycle }\left[\mathrm{Bq} \cdot \mathrm{m}^{-3}\right]\end{array}$ \\
\hline Basement & $\begin{array}{l}52 \pm 10 \\
69 \pm 12 \\
38 \pm 10 \\
55 \pm 10\end{array}$ & 53.5 & $81(17)$ \\
\hline 1 & $\begin{array}{c}<10 \\
14 \pm 8\end{array}$ & 14 & $5(3)$ \\
\hline 2 & $17 \pm 8$ & 17 & $24(9)$ \\
\hline 3 & & & $25(10)$ \\
\hline 4 & $\begin{array}{l}21 \pm 8 \\
20 \pm 8\end{array}$ & 20.5 & $26(11)$ \\
\hline 5 & $\begin{array}{l}11 \pm 8 \\
27 \pm 10\end{array}$ & 19 & \\
\hline 6 & $\begin{array}{l}22 \pm 8 \\
12 \pm 8 \\
17 \pm 8\end{array}$ & 17 & \\
\hline 7 & $23 \pm 8$ & 23 & $25(10)$ \\
\hline 8 & $22 \pm 8$ & 22 & \\
\hline 9 & $\begin{array}{l}15 \pm 8 \\
16 \pm 8 \\
22 \pm 8\end{array}$ & 17.7 & $24(10)$ \\
\hline 10 & $\begin{array}{l}20 \pm 8 \\
15 \pm 8\end{array}$ & 17.5 & \\
\hline 11 & $16 \pm 8$ & 16 & \\
\hline 12 & $<10$ & $<10$ & \\
\hline 14 & $\begin{array}{l}20 \pm 8 \\
17 \pm 8\end{array}$ & 18.5 & $29(9)$ \\
\hline 15 & $\begin{array}{l}15 \pm 8 \\
16 \pm 8\end{array}$ & 15.5 & \\
\hline 16 & $31 \pm 8$ & 31 & $32(12)$ \\
\hline Overall mean & 24 & 21.6 & 30 \\
\hline
\end{tabular}

\section{Results and discussions}

Figure 1 shows the illustrative examples that show radon time series from high-rise building, and Fig. 2 originates from the observed single-family house.

The arithmetic mean radon concentrations obtained from long- and short-term measurements are shown in Tables 1 and 2 for high-rise building and single-family house with loft, respectively.

In the family house, it is possible to notice marked variations in radon concentration with 1-day periodicity. Also interesting is the ratio of radon concentration on the ground floor to the basement of the house, which is the opposite of the usual situation in houses with a basement. This inverse behaviour can be explained by the fact that the basement does not cover the whole ground floor but a smaller part of it. The rest of the ground floor is covered by a concrete slab as a substrate, but cracks and poor joint with the walls are potential sources of elevated radon. Also, the differences in the results between two methods, passive and active devices, are due to the fact that presented radon values are measured in different seasons. With high-rise residential building, the situation is the opposite and it can be considered from the first floor that the dominant source of radon is the building material. There may even be a slight increase in the mean radon concentration on the higher floors. Also, the results show very low radon level on the first floor (well below the outdoor values) in the apartment. In such sense, we performed test intercomparison radon measurements for two active devices SN1029 and SN1030 in well-defined and controlled radon atmosphere (radon concentration below $30 \mathrm{~Bq} \cdot \mathrm{m}^{-3}$ ) in the Underground Low-background Laboratory in the Institute of Physics Belgrade $[17,18]$. Additional testing includes the same place and time of the measurements but different sampling time set to $1,2,4,8$ and $12 \mathrm{~h}$. The results are shown in Table 3.

In the above performed measurements, both devices show significant differences in the low-level radon range, which may originate from individual instruments characteristics presented in the "Materials and methods" section. 
Table 2. Results of indoor radon measurements in the single-family house with loft using passive (Radtrak ${ }^{2}$ Radonova) and active radon devices

\begin{tabular}{lcc}
\hline Floor level & $\begin{array}{c}\text { Radon concentration/Passive device } \\
\left(\text { Radtrak }^{2}\right)\left[\mathrm{Bq} \cdot \mathrm{m}^{-3}\right]\end{array}$ & $\begin{array}{c}\text { Arithmetic mean (standard deviation) radon } \\
\text { concentration over measuring cycle }\left[\mathrm{Bq} \cdot \mathrm{m}^{-3}\right]\end{array}$ \\
\hline Basement & $330 \pm 50$ & $160(202)$ \\
Ground level & $18 \pm 8$ & $579(194)$ \\
Loft & $53(21)$ \\
\hline
\end{tabular}

Table 3. Test intercomparison indoor radon measurements with active radon devices SN1029 and SN1030

\begin{tabular}{lccccc}
\hline & \multicolumn{4}{c}{ Arithmetic mean (standard deviation) } & \multicolumn{2}{c}{ radon concentration over measuring cycle $\left[\mathrm{Bq} \cdot \mathrm{m}^{-3}\right]$} \\
\hline Sampling time $[\mathrm{h}]$ & 1 & 2 & 4 & 8 & 12 \\
SN1029 & $28(12)$ & $28(11)$ & $27(7)$ & $23(6)$ & $32(14)$ \\
SN1030 & $12(6)$ & $14(7)$ & $10(3)$ & $12(5)$ & $14(6)$ \\
\hline
\end{tabular}

\section{Conclusions}

The results show that the radon behaviour in two different residential buildings is diametrically opposite. In the single-family house with loft we registered intense difference between radon concentration in the ground level and loft, while in the high-rise residential building the radon level was almost the same at all floors and hence we may conclude that radon originated mainly from building materials. However, the results from the high-rise building can be predicted on the basis of work of a group of authors who have determined the internal exposure from construction material used in Serbia which originates from the exhalation of radon and thoron [19] and the study presented in this article [10]. We can expect similar results in any other multistorey buildings in Serbia. In the future work, we will focus on the additional radon measurements in the typical residential buildings from other types of houses.

Acknowledgments. The authors acknowledge funding provided by the Institute of Physics Belgrade through the grant by the Ministry of Education, Science and Technological Development of the Republic of Serbia.

\section{ORCID}

V. Udovicic (D) http://orcid.org/0000-0002-7839-1537

\section{References}

1. Bochicchio, F., Campos-Venuti, G., Piermattei, S., Nuccetelli, C., Risica, S., Tommasino, L., Torri, G., Magnoni, M., Agnesod, G., Sgorbati, G., Bonomi, M., Minach, L., Trotti, F., Malisan, M. R., Maggiolo, S., Gaidolfi, L., Giannardi, C., Rongoni, A., Lombardi, M., Cherubini, G., D'Ostilio, S., Cristofaro, C., Pugliese, M., Martucci, V., Crispino, A., Cuzzocrea, P., Sansone Santamaria, A., \& Cappai, M. (2005). Annual average and seasonal variations of residential radon concentration for all the Italian Regions. Radiat. Meas., 40, 686-694.

2. Friedmann, H. (2005). Final results of the Austrian Radon Project. Health Phys., 89(4), 339-348.
3. Du, L., Prasauskas, T., Leivo, V., Turunen, M., Pekkonen, M., Kiviste, M., Aaltonen, A., Martuzevicius, D., \& Haverinen-Shaughnessy, U. (2015). Assessment of indoor environmental quality in existing multifamily buildings in North-East Europe. Environ. Int., 79, 74-84.

4. Cucoş (Dinu), A., Cosma, C., Dicu, T., Begy, R., Moldovan, M., Papp, B., Niță, D., Burghele, B., \& Sainz, C. (2012). Thorough investigations on indoor radon in Băița radon-prone area (Romania). Sci. Total Environ., 431, 78-83.

5. Yarmoshenko, I., Vasilyev, A., Malinovsky, G., Bossew, P., Žunić, Z. S., Onischenko, A., \& Zhukovsky, M. (2016). Variance of indoor radon concentration: Major influencing factors. Sci. Total Environ., 541, 155-160.

6. Kropat, G., Bochud, F., Jaboyedoff, M., Laedermann, J. P., Murith, C., Palacios, M., \& Baechler, S. (2014). Major influencing factors of indoor radon concentrations in Switzerland. J. Environ. Radioact., 129, 7-22.

7. Borgoni, R., De Francesco, D., De Bartolo, D., \& Tzavidis, N. (2014). Hierarchical modeling of indoor radon concentration: how much do geology and building factors matter? J. Environ. Radioact., 138, 227-237.

8. Xie, D., Liao, M., \& Kearfott, K. J. (2015). Influence of environmental factors on indoor radon concentration levels in the basement and ground floor of a building - A case study. Radiat. Meas., 82, 52-58.

9. Man, C. K., \& Yeung, H. S. (1999). Modeling and measuring the indoor radon concentrations in highrise buildings in Hong Kong. Appl. Radiat. Isot., 50, 1131-1135.

10. Vukotić, P., Zekić, R., Antović, N. M., \& Andjelić, T. (2019). Radon concentrations in multi-story buildings in Montenegro. Nucl. Technol. Radiat. Prot., 34, 165-174.

11. Lorenzo-González, M., Ruano-Ravina, A., Peón, J., Piñeiro, M., \& Barros-Dios, J. M. (2017). Residential radon in Galicia: a cross-sectional study in a radonprone area. J. Radiol. Prot., 37(3), 728-741.

12. Elío, J., Cinelli, G., Bossew, P., Gutiérrez-Villanueva, J. L., Tollefsen, T., De Cort, M., Nogarotto, A., \& Braga, R. (2019). The first version of the Pan-European Indoor Radon Map. Nat. Hazards Earth Syst. Sci., 19, 2451-2464.

13. Jovanović Popović, M., Ignjatović, D., Radivojević, A., Rajčić, A., Ćuković Ignjatović, N., Đukanović, Lj., \& Nedić, M. (2013). National typology of residential 
buildings in Serbia. Belgrade: Faculty of Architecture University of Belgrade.

14. Udovičić, V., Maletić, D., Banjanac, R., Joković, D., Dragić, A., Veselinović, N., Živanović, J., Savić, M., \& Forkapić, S. (2018). Multiyear indoor radon variability in a family house-A case study in Serbia. $\mathrm{Nucl}$. Technol. Radiat. Prot., 33(2), 174-179.

15. Maletić, D., Udovičić, V., Banjanac, R., Joković, D., Dragić, A., Veselinović, N., \& Filipović, J. (2014). Comparison of multivariate classification and regression methods for indoor radon measurements. $\mathrm{Nucl}$. Technol. Radiat. Prot., 29, 17-23.

16. Filipović, J., Maletić, D., Udovičić, V., Banjanac, R., Joković, D., Savić, M., \& Veselinović, N. (2016). The use of multivariate analysis of the radon variability in the underground laboratory and indoor environment. Nukleonika, 61(3), 357-360. DOI: 10.1515/ nuka-2016-0059.
17. Udovičić, V., Aničin, I., Joković, D., Dragić, A., Banjanac, R., Grabež, B., \& Veselinović, N. (2011). Radon time-series analysis in the Underground Low-level Laboratory in Belgrade, Serbia. Radiat. Prot. Dosim., 145(2/3), 155-158.

18. Udovičić, V., Filipović, J., Dragić, A., Banjanac, R. Joković, D., Maletić, D., Grabež, B., \& Veselinović, N. (2014). Daily and seasonal radon variability in the underground low-background laboratory in Belgrade, Serbia. Radiat. Prot. Dosim., 160(1/3), 62-64.

19. Ujić, P., Čeliković, I., Kandić, A., Vukanac, I., Đurašević, M., Dragosavac, D., \& Žunić, Z. S. (2010). Internal exposure from building materials exhaling ${ }^{222} \mathrm{Rn}$ and ${ }^{220} \mathrm{Rn}$ as compared to external exposure due to their natural radioactivity content. Appl. Radiat. Isot., 68, 201-206. 